\title{
KREATIVITAS GURU MATEMATIKA KELAS VIII DALAM PEMBELAJARAN MATEMATIKA DI MTSN MODEL MARTAPURA
}

\author{
Maulida Rezkia \& Sessi Rewetty Rivilla
}

\begin{abstract}
Abstrak
Penelitian ini bertolak dari pembelajaran yang melibatkan anak-anak sebagai salah satu komponen dasarnya, dimana dalam pembelajaran tersebut menuntut kreativitas guru mata pelajaran matematika dalam melaksanakan pembelajaran sesuai dengan karakteristik anak. Sehingga penting untuk melakukan penelitian yang bertujuan untuk mengetahui bagaimana kreativitas guru pada mata pelajaran matematika.

Penelitian ini adalah penelitian lapangan (field research) dengan pendekatan kualitatif dengan analisis deskriptif kualitatif. Subjek dalam penelitian ini adalah guru yang mengajar matematika di kelas VIII dan objek adalah kreativitas guru dalam pembelajaran matematika.

Hasil penelitian menunjukkan bahwa Kreativitas guru dalam perencanaan pembelajaran, guru selalu merevisi RPP jika ada hal-hal yang kurang sesuai untuk dilaksanakan. Adapun pelaksanaan pembelajaran dimulai dengan kegiatan pendahuluan dimana guru memasuki kelas tepat waktu, menggunakan aplikasi pada handphone (HP) untuk mengabsen siswa, membahas PR dan melakukan pre test secara lisan. Adapun kreativitas dalam kegiatan inti yaitu guru menggunakan powerpoint untuk menyampaikan materi, wondershare quizcreator untuk latihan soal, menyelipkan humor, menayangkan video motivasi, dan memutar musik instrumental pada saat siswa mengerjakan latihan soal. Sedangkan kreativitas guru dalam kegiatan penutup, guru mengadakan post test, merangkum materi yang telah dipelajari bersama siswa, memberikan pekerjaan rumah, dan meminta siswa untuk mempelajari materi pertemuan selanjutnya yang bersumber dari edukasinet. Evaluasi pembelajaran terdiri dari evaluasi kegiatan pembelajaran dan evaluasi hasil belajar. Adapun untuk evaluasi hasil belajar, guru mengadakan pre test pada kegiatan pendahuluan, latihan-latihan soal pada kegiatan inti, dan post test pada kegiatan penutup. Untuk penilaian selama proses pembelajaran, guru menggunakan format penilaian pada aplikasi di handphone.
\end{abstract}

Kata Kunci: Kreatifitas guru dan pembelajaran matematika 


\section{Pendahuluan}

Proses belajar mengajar adalah suatu bentuk permasalahan yang sangat kompleks, karena didalamnya melibatkan banyak unsur yang saling berkaitan sehingga keberhasilannya juga ditentukan oleh unsur-unsur tersebut, terutama guru sebagai proses pengendali lajunya proses pembelajaraan.

Menurut Nana Sudjana (1989 : 29) proses pembelajaran adalah proses berubahnya tingkah laku siswa dari berbagai pengalaman yang diperolehnya. Jadi dalam kegiatan ini akan melibatkan berbagai komponen yang saling berinteraksi untuk mencapai tujuan yang diharapkan.

Guru sebagai salah satu komponen pendidikan sangat menentukan keberhasilan pendidikan, karena mereka terlibat langsung di dalamnya, sebagai mana menurut Moh. Uzer Usman (2006 : 9) tugas dan peranan guru antara lain: komunikator (penguji materi pelajaran kepada siswa), fasilitator (memberikan pelayanan kepada siswa dalam belajar), motivator (memberikan dorongan/motivasi kepada siswa dalam belajar), figur (model yang dapat dicontoh dan diteladani keperibadiannya), evaluator (pihak yang menilai keberhasilan pendidikan), narasumber (guru sebagai salah satu sumber belajar menjadi tumpuan peserta didiknya dalam mencari informasi dan penjelasan, terutama mengenai kesulitan dalam memahami materi pelajaran).

Kewajiban pertama pendidik dan tenaga kependidikan (untuk selanjutnya difokuskan pada guru) yang diatur dalam Undang-Undang Republik Indonesia Nomor 20 Tahun 2003 tentang Sistem Pendidikan Nasional (SISDIKNAS), pasal 40, ayat (2), ialah, "menciptakan suasana pendidikan yang bermakna, meyenangkan, kreatif, dinamis, dan dialogis (Direktorat Jenderal Pendidikan Islam Departemen Agama RI Tahun 2006 : 28)

Matematika sebagai salah satu pelajaran yang diajarkan di semua jenjang pendidikan, memiliki peranan yang sangat penting dalam kehidupan dan dalam mempelajari bidang yang lain. Selain itu, matematika 
Kreativitas Guru Matematika Kelas VIII dalam Pembelajaran Matematika di MTSN Model Martapura

adalah sarana berpikir logis, sistematis, dan konsisten. Matematika juga merupakan ilmu universal yang mendasari perkembangan ilmu sains dan teknologi, serta berperan besar dalam mengembangkan daya pikir manusia.

Kegiatan pembelajaran matematika adalah pembelajaran yang melibatkan anak-anak sebagai salah satu komponen dasarnya, dimana dalam pembelajaran tersebut menuntut kreasi guru mata pelajaran matematika dalam menyajikan materi sesuai dengan karakteristik anak.

Menurut Noraini Idris (dalam Seri Ningsih 2011) mengatakan bahwa, pada pembelajaran matematika di sekolah, sebagian besar guru masih mendominasi proses mengajar belajar dengan menerapkan pembelajaran yang menganut teori behaviorisme seperti model pembelajaran langsung (Direct Intruction). Umumnya guru memulai pembelajaran langsung pada pemaparan materi, kemudian pemberian contoh oleh guru dan selanjutnya mengevaluasi siswa melalui latihan soal. Padahal memahami pembelajaran matematika bukanlah hal mudah. Banyak siswa gagal memahami konsep yang diberikan oleh guru. Siswa menerima pelajaran matematika secara pasif dan bahkan hanya menghapal rumus-rumus tanpa memahami makna dan manfaat dari apa yang dipelajari. Akibatnya prestasi belajar matematika di sekolah masih relatif rendah.

Sebagaimana ditulis Mutrofin (dalam Guntur Talajan, 2012 : 53) menyatakan bahwa jika di jenjang pendidikan dasar banyak siswa SD stres lantaran mata ajar yang yang mereka terima semakin menumpuk dan terlalu berat, maka di jenjang pendidikan menengah matematika telah menjadi momok paling menakutkan bagi para siswa. Mata ajar matematika mulai dirasakan sebagai bencana sejak tahun 1970-an, yakni manakala mata ajar berhitung mulai ditinggalkan dan diganti dengan new mathematic. New math sendiri pada prinsipnya kaya akan konsep fungsi, konsep hitungan, konsep logika, dan lain-lain. Melebihi konsep aritmatika (berhitung) yang dikembangkan terdahulu. Namun sayang, masuknya matematika dalam kurikulum pendidikan sekolah di Indonesia, sebelumnya tidak disertai penyediaan sumber daya manusia (guru) yang 
memadai.Hanya guru matematika kreatif dan berprestasi yang akan mampu menjembatani ketakutan dan kesulitan para siswa dalam mempelajari matematika.

Selama proses pembelajaran berlangsung, berbagai perasaan bisa terjadi pada setiap siswa, misalnya senang dan susah, bosan atau jenuh, malas, tidak punya perhatian dan lain sebagainya. Apabila terjadi seperti itu, guru harus segera kreatif mengatasinya, agar siswa menjadi semangat, bergairah dan penuh motivasi, sehingga pembelajaran akan berjalan secara efektif dan efisien.

Untuk mewujudkan proses pembelajaran matematika yang lebih bermakna sehingga prestasi belajar siswa yang diperoleh tinggi, guru harus kreatif dan inovatif dalam mengembangkan kegiatan pembelajaran ketika proses belajar mengajar berlangsung. Kegiatan pembelajaran dirancang sedemikian rupa untuk memberikan pengalaman belajar yang melibatkan proses mental dan fisik melalui interaksi antar siswa, siswa dengan guru, lingkungan dan sumber belajar lainnya dalam rangka pencapaian tujuan pembelajaran.

Menurut Sunaryo (dalam Guntur Talajan, 2012 : 54) menyatakan bahwa dalam pelaksanaan pembelajaran, guru dituntut memiliki berbagai keterampilan atau kreativitas belajar, strategi belajar mengajar yang tepat, dan kemampuan melaksanakan evaluasi yang baik. Dengan wawasan yang luas diharapkan guru mampu memperhitungkan berbagai kemungkinan yang akan terjadi dengan pertimbangan kondisi sekarang dan pengalaman masa lalu. Tujuannya adalah agar guru dapat memahami bahwa dalam melaksanakan fungsi dan perannya sebagai fasilitator pendidikan, guru diharapkan mempunyai kemampuan dan kreativitas dalam menjalankan kegiatan mengajar sebagai transforming science kepada peserta didik sebagai penerima dan pengembang ilmu yang telah diberikan oleh guru selama kegiatan pengajaran berlangsung di dalam kelas.

Menurut Rina Eny Anawati (dalam Jamal Ma'mur Asmani, 2010 : 27) menyatakan bahwa proses kreatif dalam pembelajaran sangat penting 
Kreativitas Guru Matematika Kelas VIII dalam Pembelajaran Matematika di MTSN Model Martapura

bagi seorang guru. Menciptakan suasana kelas yang penuh inspirasi bagi siswa, kreatif, dan antusias merupakan salah satu tugas dan tanggung jawab seorang guru. Dengan begitu waktu belajar menjadi saat yang dinantinantikan oleh siswa.Selain itu, kualitas pembelajaran sangat ditentukan oleh aktivitas dan kreativitas guru, disamping kompetensi-kompetensi profesionalnya.

Gutur Talajan (2012 : 44-45) mengatakan Pada tahun 2009, komisi Eropa meluncurkan hasil survei tentang presepsi para guru di Eropa perihal kreativitas dengan tajuk Creativity in School in Europe. A survey of Teachers. Survei tersebut diumumkan berkaitan dengan Tahun Kreativitas dan Inovasi Uni Eropa 2009. Survei yang dilaksanakan secara online terhadap sampel 12.893 responden guru yang tersebar di 32 negara anggota Uni Eropa - yang dapat dianalisis 9.460 dari 27 negara - sangat menarik dikemukakan karena presepsi para guru tentang kreativitas sudah demikian luas. Hasil analisis menunjukkan bahwa lebih dari 95\% respon guru sependapat dan memahami bahwa kreativitas merupakan atribut yang dapat diaplikasikan terhadap setiap domain pengetahuan, berbagai subjek sekolah, dan oleh karenanya para guru pada umumnya berpendapat bahwa kreativitas merupakan kompetensi fundamental di sekolah.Secara subtansial mayoritas guru (94\%) mendukung gagasan bahwa kreativitas adalah sebuah keterampilan mendasar yang penting dikembangkan di sekolah-sekolah.

Berdasarkan informasi yang peneliti dapatkan dari penjajakan awal di MTsN Model Martapura bahwa MTsN model Martapura merupakan salah satu sekolah favorit berdasarkan dari banyaknya lulusan SD/MI yang ingin melanjutkan studinya ke MTsN Model Martapura dan dari beberapa penghargaan yang didapat oleh MTsN Model Martapura serta prestasiprestasi yang diraih oleh siswa-siswinya. Di sekolah MTsN Model Martapura terdapat guru matematika kelas VIII yang memiliki karakteristik guru kreatif. Karakteristik guru kreatif diantaranya disiplin, inspiratif, dan berdasarkan prestasi-prestasi yang guru raih. 


\section{Metode Penelitian}

\section{Jenis, Pendekatan dan Metode Penelitian}

Jenis penelitian ini adalah penelitian lapangan (field research). Dalam penelitian ini penulis menggunakan pendekatan kualitatif. Menurut Margono (2007 : 36) penelitian kualitatif yaitu prosedur penilitian yang menghasilkan data deskriptif berupa kata tertulis atau lisan dari orang-orang dan perilaku yang diamati. Sedangkan metode yang digunakan dalam penelitian ini adalah metode deskriptif, yaitu suatu metode dalam meneliti status kelompok manusia, suatu objek suatu set kondisi, suatu sistem pemikiran ataupun suatu kelas peristiwa pada masa sekarang. Metode ini bertujuan untuk membuat deskripsi, gambaran, atau lukisan secara sistematis, faktual, dan akurat mengenai faktor-faktor serta hubungan antara fenomena yang diselidiki (M. Nasir, 1997 : 63).

Penelitian pendekatan kualitatif dengan metode deskriptif ini bertujuan untuk memperoleh gambaran mengenaikreativitas guru matematika kelas VIII dalam pembelajaran matematika di MTsN Model Martapura. Penelitian ini menggunakan pendekatan kualitatif dengan metode deskriptif karena skor atau cakupan nilai kreativitas belum disepakati.

\section{Subjek dan Objek Penelitian}

Adapun yang menjadi subjek penelitian di dalam penelitian ini adalah satu orang guru matematika yang mengajar di kelas VIlldi MTsN Model Martapura yang dijadikan sebagai informan.Pemilihan subjek dilihat berdasarkan prestasi, dan kemampuan serta kegiatan dan karakteristik dari guru tersebut yang memiliki beberapa kriteria guru kreatif. Objek penelitian dalam penelitian ini adalah kreativitas guru dalam pembelajaran matematika di kelas VIII MTsN Model Martapura.

\section{Teknik Pengumpulan Data}

Dalam penelitian ini digunakan teknik pengumpulan data berupa wawancara, dan observasi. Wawancara digunakan untuk memperoleh informasi tentang usaha-usaha kreatif guru matematika dalam 
Kreativitas Guru Matematika Kelas VIII dalam Pembelajaran Matematika di MTSN Model Martapura

merencanakan pembelajaran baik yang menyangkut perangkat pembelajaran maupun strategi yang akan digunakan guru dalam mengajar, kegiatan kreatif guru saat pembelajaran berlangsung, serta sistem penilaian kreatif guru matematika dalam menilai hasil belajar peserta didik. Observasi dilakukan dengan cara mengamati proses kegiatan belajar mengajar Matematika di kelas VIII C dan VIII D dari empat kelas yang diampu oleh guru yang menjadi informan. Observasi ini dilakukan untuk mendapatkan informasi tentang peristiwa, aktifitas, perilaku, dan benda yang berkaitan dengan kegiatan kreatif guru saat pembelajaran berlangsung.

\section{Teknik Analisis Data}

Analisis data adalah proses mencari dan menyusun secara sistematis data yang diperoleh dari hasil wawancara, catatan lapangan, dan dokumentasi, dengan cara mengorganisasikan data kedalam kategori, menyusun kedalam pola dan memilh mana yang penting dan yang akan dipelajari.Aktivitas dalam analisis data yaitu data reduction, data display, dan conclusion drawing/verification (Sugiyono, 2012 : 246)

a. Data Reduction (reduksi data)

Mereduksi data berarti merangkum, memilih hal-hal yang pokok, memfokuskan pada hal-hal yang penting, dicari tema dan polanya (Sugiyono, 2012 : 247). Kegiatan ini bertujuan untuk mempertegas, memperpendek, membuat fokus, membuang hal-hal yang tidak penting yang muncul dari catatan dan pengumpulan data. Proses ini berlangsung terus-terus menerus sampai laporan akhir penelitian selesai. Adapun dalam mereduksi data peneliti memfokuskan pada kreativitas guru dalam pembelajaran matematika yang meliputi perencanaan, pelaksanaan pembelajaran dan pelaksanaan evaluasi.

b. Data Display (penyajian data)

Setelah data direduksi, maka langkah selanjutnya adalah mendisplaykan data. Dalam penelitian kualitatif, penyajian data dapat dilakukan dengan uraian singkat, bagan, hubungan antar kategori, 
flowchart dan sejenisnya. Dalam hal ini Miles dan Huberman menyatakan "The most frequent form of display data for qualitative research data in the past has been narrative text". Yang paling sering digunakan untuk penyajian data dalam penelitian kualitatif adalah dengan teks yang bersifat naratif (Sugiyono, 2012 : 249). Penyajian data dalam penelitian kualitatif dimaksudkan untuk menemukan suatu makna dari kata-kata yang diperoleh, kemudian disusun secara sistematis dan logis dari bentuk informasi yang kompleks menjadi sederhana namun selektif sehingga bisa lebih mudah dipahami.

c. Conclusion Drawing/verification

Langkah ke tiga dalam analisis data kualitatif menurut Miles dan Huberman adalah penarikan kesimpulan dan verifikasi. Kesimpulan awal yang dikemukakan masih bersifat sementara, dan akan berubah bila tidak ditemukan bukti-bukti yang kuat yang mendukung pada tahap pengumpulan data berikutnya. Tetapi apabila kesimpulan yang dikemukakan pada tahap awal, didukung oleh bukti-bukti yang valid dan konsisten saat peneliti kembali ke lapangan mengumpulkan data, maka kesimpulan yang dikemukakan merupakan kesimpulan yang kredibel (Sugiyono, 2012 : 252).

Mengambil kesimpulan merupakan langkah analisis setelah pengolahan data. Kesimpulan yang diambil mungkin masih terasa kabur dan diragukan. Oleh karena itu, perlu dilakukan verifikasi kesimpulan tersebut dengan mencari data-data lain yang dapat mendukung kesimpulan tersebut serta dengan mengecek ulang data-data yang telah diperoleh.

\section{Hasil dan Pembahasan}

Setelah data diperoleh dari hasil wawancara dan observasi yang berkenaan dengan kreativitas guru kelas VIII dalam pembelajaran matematika, maka dapat dianalisis data secara sederhana, sehingga pada akhirnya dapat memberikan gambaran apa yang diinginkan dalam penelitian ini. Adapun analisis data yang dipaparkan sebagai berikut. 
Kreativitas Guru Matematika Kelas VIII dalam Pembelajaran Matematika di MTSN Model Martapura

1. Analisis Kreativitas guru dalam perencanaan pembelajaran

Kreativitas guru dalam merencanakan pembelajaran dapat dilihat dari cara guru membuat perangkat pembelajaran yang baru sesuai perkembangan kurikulum dan dengan revisi dari tahun sebelumnya, serta berpedoman pada BSNP. Guru juga menggunakan pengalaman pelaksanaan pembelajaran pada tahun sebelumnya sebagai masukan dalam penyusunan perangkat pembelajaran berikutnya. Selain itu guru juga memperhatikan karakteristik materi yang akan diajarkan dengan kadar kemampuan siswa sehingga akan ada kesesuaian antara materi yang diajarkan dengan kadar kemampuan siswa, dengan adanya kesesuaian diharapkan hasil belajar siswa akan optimal. Dengan demikian terlihat bahwa guru sudah kreatif karena membuat perencanaan tidak hanya sekedar copy-paste dari tahun sebelumnya.

Dalam memilih materi, media dan sumber belajar, guru menyampaikan materi yang sesuai dengan tujuan pembelajaran, serta memberikan kedalaman materi sesuai dengan tuntutan kelas. Hal tersebut selaras dengan pendapat Jamal Mamur Asmani (2010 : 23) bahwa "ciri-ciri guru berkepribadian kreatif adalah fleksibel dimana guru dapat memahami kondisi peserta didik". Adapun dalam pemilihan media, guru memilih powerpoint dan wondershare quizcreator. Selaras dengan pendapat Budi Purwanto (dalam Guntur talajan, 2012 : 61-65) bahwa fokus kreativitas guru dalam pembelajaran khususnya pada cara guru dalam merencanakan pembelajaran, guru harus menciptakan media atau alat peraga yang sesuai dan menarik minat dimana penggunaan media atau alat peraga akan memperlancar tercapainya tujuan pembelajaran.

Kreativitas guru dalam menentukan sumber belajar dapat dilihat dari cara guru dalam menggunakan berbagai sumber sebagai bahan acuan dalam mengajar. Dalam hal ini Budi Purwanto (dalam Guntur talajan, 2012 : 61-65) juga menegaskan bahwa guru tidak hanya sekedar berorientasi kepada layaknya buku yang harus dipegang oleh peserta 
didik, melainkan buku yang digunakan benar-benar mempunyai bobot materi yang menunjang pencapaian kurikulum bahkan mampu mengembangkan wawasan bagi peserta didik di masa yang akan datang. Sebagaimana guru tidak hanya memiliki buku LKS yang dipegang oleh siswa melainkan juga memiliki bahan acuan lainyaitu edukasinet dan BSE.

2. Analisis Kreativitas dalam Pelaksanaan Pembelajaran

Kegiatan pembelajaran terdiri dari kegiatan pendahuluan, inti dan penutup. Dari data yang telah disajikan dapat dilihat bahwa guru tepat waktu dalam memulai dan mengakhiri pembelajaran, selaras dengan pendapat Jamal Ma'mur Asmani (2010 : 20) yang mengatakan bahwa guru ideal adalah guru yang sensitif dengan waktu. Dengan kata lain, guru menggunakan waktu secara efesien dalam melaksanakan pembelajaran.

Adapun kegiatan inti, kreativitas guru dapat dilihat bahwa dalam menyampaikan materi pembelajaran guru menyesuaikan kedalaman materi sesuai dengan tuntunan kelas. Media yang guru gunakan dalam pembelajaran yaitu powerpoint dan untuk latihan guru menggunakan wondershare quizcreator. dimana kedua media tersebut sangat membantu guru dalam memperlancar proses pembelajaran. Selaras dengan pendapat Budi Purwanto (dalam Guntur talajan, 2012 : 61-65) yang mengatakan bahwa penggunaan alat media yang menarik akan membangkitkan motivasi belajar siswa. Selain itu, salah satu cermin keberhasilan guru dalam pembelajaran adalah kemampuannya dalam mengkreasi media pembelajaran.

Dalam memilih metode, kreativitas guru dapat dilihat dengan pemilihan metode yang sesuai dengan pembelajaran. Dimana, dalam menyampaikan materi guru menggunakan metode ekspositori dan tanya jawab, dan dalam pemberian tugas siswa langsung menjawab dikelas atau pekerjaan rumah, apabila siswa kesulitan dalam menjawab latihan maka guru menggunakan metode diskusi yaitu boleh bertanya dengan teman yang lainnya. 
Kreativitas Guru Matematika Kelas VIII dalam Pembelajaran Matematika di MTSN Model Martapura

Hal tersebut senada dengan pendapat Budi Purwanto (dalam Guntur talajan, 2012 : 61-65) yang menyatakan bahwa kreativitas guru dalam memilih metode, guru harus memilih metode yang baik dan harus selalu menyesuaikan dengan materi pelajaran dan kondisi peserta didik. Pada dasarnya semua metode itu baik, akan tetapi tidak semua metode dapat digunakan dalam semua mata pelajaran, dalam hal ini guru dituntut untuk kreatif dalam memilih metode yang sesuai dengan materi pelajaran dan kondisi peserta didik.

Tidak dapat dipungkiri bahwa dalam proses pembelajaran adakalanya siswa, bahkan guru mengalami kejenuhan. Hal ini tentu menjadi masalah bagi tercapainya tujuan pembelajaran. Untuk mengatasi kejenuhan tersebut perlu diciptakan situasi dan kondisi pembelajaran yang bervariasi. Guru yang mampu menghadirkan proses pembelajaran yang bervariasi kemungkinan besar kejenuhan tidak akan terjadi. Oleh karenanya tantangan dalam pembelajaran sangat membutuhkan guru yang kreatif agar siswa berminat dalam mengikuti proses pembelajaran. Adapun kreativitas yang dapat dilihat dalam proses pembelajaran adalah guru dapat melaksanakan kegiatan pembelajaran secara bervariasi diantaranya: guru memutar musik instrumen saat siswa sedang menyelesaikan soal latihan yang telah diberikan guru, dimana musik tersebut dapat membangkitkan semangat siswa dalam menyelesaikan soal. Guru juga memberikan selingan berupa humor dan menayangkan video yang berisikan motivasi, yang dapat membangkitkan semangat belajar siswa. Selain itu, guru juga memiliki variasi dalam penguatan suara, sangat jelas, baik dan tegas dalam mengintonasikan suatu peristiwa. Misal guru menggunakan kalimat "tolong diingat", "tolong diperhatikan", dan "silahkan keluar apabila ingin berbicara". Penekanan ini penting agar siswa mengetahui hal-hal yang dianggap penting dari mata pelajaran yang disampaikan guru.

Adapun kreativitas guru dalam menutup pembelajaran dapat terlihat dari guru mengadakan post test, merangkum materi yang telah 
dipelajari, memberikan pekerjaan rumah, dan meminta siswa untuk mempelajari materi untuk pertemuan selanjutnya yang bersumber dari edukasinet. Tujuannya agar siswa dapat menambah wawasan berkaitan dengan materi yang telah disampaikan.

3. Analisis Kreativitas dalam Evaluasi Pembelajaran

Berdasarkan data yang telah disajikan, dapat dilhat bahwa kreativitas guru dalam mengadakan evaluasi, bahwa guru melakukan refleksi kegiatan pembelajaran dimana pabila terdapat ketidaksesuaian kegiatan pembelajaran dengan RPP maka guru akan mencari solusi untuk kegiatan pembelajaran yang akan datang. Adapun untuk evaluasi hasil belajar guru memiliki penilaian yangdibuat pada aplikasi di hand phone, tujuannya agar guru bisa langsung menilai keaktifan siswa pada proses pembelejaran. Menurut Utami Munandar (1995 : 25) apabila guru menciptakan hal yang baru maka guru tersebut memiliki sifat kreatif, dimana disini guru membuat sesuatu yang baru dalam format penilaian selama proses pembelajaran.

4. Analisis Karakteristik kreatif guru Matematika Kelas VIII

Berdasarkan observasi dan wawancara bahwa guru matematika kelas VIII dapat dikatakan guru kreatif berdasarkan prestasi, dan kemampuan serta kegiatan dan karakteristik dari guru tersebut. Prestasi guru dapat dilihat dari semenjak bangku kuliah dimana guru sudah aktif mengajar. Kegiatan guru selain mengajar juga aktif dalam organisasi ke Islaman dimana beliau sering diundang memberikan ceramah. Kemudian, dari 24 indikator kepribadian kreatif menurut Dedi Supriadi (dalam Guntur Talajan, 2012 : 29-30) guru tersebut memenuhi 13 indikator yang dilihat penulis pada saat observasi, wawancara dengan guru yang bersangkutan dan wawancara dengan salah satu guru. Adapun selebihnya adalah kekurangtahuan penulis karena tidak bergaul dengan guru dalam keseharian. 
Kreativitas Guru Matematika Kelas VIII dalam Pembelajaran Matematika di MTSN Model Martapura

\section{Kesimpulan}

Berdasarkan penelitian tentang Kreativitas Guru Matematika Kelas VIII dalam Pembelajaran Matematika di MTsN Model Martapura, guru selalu merivisi RPP, menyesuaikan materi yang akan diajarkan dengan kemampuan siswa, memilih powerpoint dan wondershare quizcreator sebagai media pembelajaran, menggunakan bahan acuan dalam mengajar, yaitu LKS, edukasinet, dan BSE.

Dalam pelaksanaan pembelajaran dimulai dengan kegiatan pendahuluan dimana guru memasuki kelas tepat waktu, mengunakan aplikasi pada handphone (HP) untuk mengabsen siswa, membahas PRdan melakukan pretest secara lisan untuk mengulang pelajaran pada pertemuan sebelumnya. Adapun kreativitas dalam kegiatan inti yaitu guru menggunakan powerpoint untuk menyampaikan materi, wondershare quizcreator untuk latihan soal, menyelipkan humor, menayangkan video motivasi, dan memutar musik instrumental pada saat siswa mengerjakan latihan soal. Sedangkan kreativitas guru dalam kegiatan penutup, guru mengadakan post test, merangkum materi yang telah dipelajari bersama siswa, memberikan pekerjaan rumah, dan meminta siswa untuk mempelajari materi pertemuan selanjutnya yang bersumber dari edukasinet.

Evaluasi pembelajaran terdiri dari evaluasi kegiatan pembelajaran dan evaluasi hasil belajar. Pada evaluasi kegiatan pembelajaran, guru merefleksi kegiatan pembelajaran ketika terdapat ketidaksesuaian dengan RPP dan mecari solusi untuk kegiatan pembelajaran yang akan datang. Adapun untuk evaluasi hasil belajar, guru mengadakan pretest pada kegiatan pendahuluan, latihan-latihan soal pada kegiatan inti, dan post testpada kegiatan penutup. Untuk penilaian selama proses pembelajaran, guru menggunakan format penilaian pada aplikasi di handphone. 
Maulida Rezkia \& Sessi Rewetty Rivilla

\section{Daftar Pustaka}

Asmani, Jamal Ma'mur, Tips Menjadi Guru Yang Inspiratif, Kreatif, dan Inovatif, Jogjakarta, DIVA Press, 2010.

Direktorat Jenderal Pendidikan Islam Departemen Agama RI Tahun 2006, Undang-Undang dan Peraturan Pemerintah RI Tentang Pendidikan,Jakarta, Direktorat Jenderal,2006.

Margono, S. Metodologi Peniltian Pendidikan, Jakarta, PT. Rineka Cipta, 2007.

Munandar, Utami, Pengembangkan Kreativitas Anak Berbakat, Jakarta, PT.Rineka Cipta,1999.

Nasir, M.Metode penelitian, Jakarta, Graha Indonesia, 1997.

Ningsih, Seri, “Eksperimentasi Model Pembelajaran Kooperatif Teknik Make A Match Ditinjau Dari Aktivitas Belajar Siswa". Jurnal Ilmiah Pendidikan Guru Madrasah Ibtidaiyah, Vol. I, No. 02, Juli 2011.

Sudjana, Nana,Dasar-Dasar Proses Belajar Mengajar,Bandung, PT. Sinar Baru Slengensindo,1989.

Sugiyono, Metode Penelitian Pendidikan pendekatan Kuantitatif, Kualitatif, dan $R \& D$, Bandung, Alfabeta, 2012.

Talajan, Guntur, Menumbuhkan Kreativitas dan Prestasi Guru, Yogyakarta, PRESSindo, 2012.

Usman, Moh. Uzer, Menjadi Guru Profesional, Bandung, PT. Remaja Rosdakarya, 2006.

\section{Sessi Rewetty Rivilla}

IAIN Antasari, Banjarmasin

E-mail: -

\section{Maulida Rezkia}

IAIN Antasari, Banjarmasin

E-mail: maulidarezkia@yahoo.com 